\title{
New species of Hasemania (Characiformes: Characidae) from Central Brazil, with comments on the endemism of upper rio Tocantins basin, Goiás State
}

\author{
Vinicius A. Bertaco and Fernando R. Carvalho
}

Hasemania kalunga is described from the upper rio Tocantins basin, Chapada dos Veadeiros, Goiás State, Brazil. The new species is distinguished from its congeners by the number of perforated lateral line scales (11-21 vs. 5-9, except from $H$. crenuchoides and $H$. piatan), by the presence of a black vertically-elongate humeral spot (vs. absent, except from $H$. crenuchoides, H. nambiquara, and H. piatan), and by absence of scale sheath along anal-fin base (vs. presence, except from H. maxillaris, and H. piatan), by 19 principal caudal-fin rays (vs. 18 in $H$. piatan). It differs also from $H$. crenuchoides by morphometric data. The absence of scale sheath covering the anal-fin base, an uncommon character in Characidae, and the endemism of the ichthyofauna from the upper rio Tocantins are discussed.

Hasemania kalunga é descrita para a bacia do alto rio Tocantins, Chapada dos Veadeiros, Goiás, Brasil. A espécie nova distingue-se das suas congêneres pelo número de escamas perfuradas da linha lateral (11-21 vs. 5-9, exceto de H. crenuchoides e $H$. piatan), pela presença de uma mancha umeral preta e verticalmente alongada (vs. ausência, exceto de $H$. crenuchoides, $H$. nambiquara e $H$. piatan), e pela ausência de escamas na base da nadadeira anal (vs. presença, exceto de H. maxillaris e $H$. piatan), por 19 raios principais na nadadeira caudal (vs. $18 \mathrm{em} \mathrm{H}$. piatan). Ela também difere de H. crenuchoides por dados morfométricos. A ausência de uma bainha de escamas cobrindo a base da nadadeira anal, um caráter incomum em Characidae, e o endemismo da ictiofauna do alto rio Tocantins são discutidos.

Key words: Chapada dos Veadeiros, Endemism, Neotropical fish, Hasemania crenuchoides.

\section{Introduction}

Hasemania is a small Characidae incertae sedis genus (sensu Lima et al., 2003), proposed by Ellis (1911) to include H. maxillaris, H. melanura (type species) and H. bilineata $(=$ Coptobrycon bilineatus). It differs from other characids mainly by the absence of an adipose fin. The presence of two series of teeth in the premaxilla, the maxilla with few or no teeth along its exposed anterior margin, the incomplete lateral line, and naked caudal fin led Ellis (1911: 148) to consider the new genus "like Hyphessobrycon, but without an adipose". Later, Eigenmann (1921) recognized the same species of Ellis in his revision. Géry (1977) followed Eigenmann and Ellis, and further included the genus in a group he named "Hemigrammus and allied genera". Publications on Hasemania subsequent to Eigenmann's revision, involve mainly the transfer of Pristicharax hanseni to Hasemania hanseni by Böhlke (1958) and Tetragonopterus nanus to Hasemania nana by Géry (1972), and descriptions of new species by Zarske \& Géry (1999), Bertaco \& Malabarba (2007), and Zanata \& Serra (2010).

Currently, seven valid species are recognized in Hasemania, three with a limited distribution in the rio Paraná basin $(H$. crenuchoides Zarske \& Géry from the upper rio Paraná; $H$. maxillaris Ellis and H. melanura Ellis from rio Iguaçu), rio São Francisco basin (H. nana); one species from an unknown locality in the state of Goiás, Brazil (H. hanseni (Fowler)), one from the upper rio Tapajós basin (H. nambiquara), and one from the upper rio de Contas drainage (Lima et al., 2003; Bertaco \& Malabarba, 2007; Zanata \& Serra 2010).

In a recent expedition to tributaries from the upper rio Tocantins basin in the Chapada dos Veadeiros, Goiás State, Central Brazil, a new characid species referable to Hasemania was discovered and is described herein. The new species is allocated in Hasemania because it fits best in the traditional diagnosis of the genus given by Ellis (1911) and subsequent authors.

\section{Material and Methods}

Counts and measurements follow Fink \& Weitzman (1974), with the exception of the number of scale rows below the lateral line, which followed Bertaco \& Lucena (2006). Vertebrae,

Universidade Federal do Rio Grande do Sul, Instituto de Biociências, Departamento de Zoologia, Laboratório de Ictiologia. Av. Bento Gonçalves, 9500, 91501-970 Porto Alegre, RS, Brazil. vbertaco@gmail.com; frcarvalho2004@yahoo.com.br 
supraneurals, gill-rakers on the first arch, and procurrent caudal-fin ray counts were taken from cleared and stained specimens (c\&s) prepared according to Taylor \& van Dyke (1985). Vertebral counts include the four vertebrae of the Weberian apparatus, and the terminal centrum counted as a single element. Pattern of circuli and radii was defined on scales sampled from region between the lateral line and the insertion of pelvic-fin. The values for the holotype are indicated by an asterisk. SEM (scanning electron micrographs) photos were taken from the cleared and stained dissected specimen. Measurements were taken point-to-point with an electronic caliper on the left side of specimens. All measurements other than standard length (SL) are expressed as a percentage of SL except for subunits of the head, which are presented as a percentage of head length (HL).

The specimens examined are deposited in the Departamento de Zoologia e Botânica, IBILCE/UNESP, São José do Rio Preto (DZSJRP), Museu de Ciências e Tecnologia da Pontifícia Universidade Católica do Rio Grande do Sul, Porto Alegre (MCP), Museu Nacional, Rio de Janeiro (MNRJ), Museu de Zoologia da Universidade de São Paulo, São Paulo (MZUSP), and Departamento de Zoologia, Universidade Federal do Rio Grande do Sul, Porto Alegre (UFRGS).

\section{Hasemania kalunga, new species Figs. 1-2}

Holotype. MCP 44289, female, 53.3 mm SL, Brazil, Goiás State, Cavalcante, córrego in the road GO 241 between Cavalcante and Minaçu, tributary of rio das Almas, rio Paranã drainage, upper rio Tocantins basin, $1163 \mathrm{~m}$ a.s.1., 13³6'56.7'S 47³1'06.6”W, 7 Sep 2009, V. A. Bertaco, F. R. Carvalho \& G. Frainer.

Paratypes. DZSJRP 12339, 12, 19.8-38.6 mm SL; MCP 44290, 12 , 19.9-43.3 mm SL; MZUSP 104303, 12, 20.8-43.4 mm SL; UFRGS 11288, 37 (ethyl alcohol anhydrous) 15.5-24.0 mm SL; UFRGS $11289,82,5$ c\&s, 15.5-53.3 mm SL, collected with the holotype.

Diagnosis. Hasemania kalunga is distinguished from its congeners by the number of perforated lateral line scales (1121 vs. 5-9, except from H. crenuchoides and H. piatan), by the presence of a black vertically-elongate humeral spot ( $v s$. absent, except from $H$. crenuchoides, $H$. nambiquara, and $H$. piatan), and by absence of scale sheath along anal-fin base (vs. presence, except from $H$. maxillaris and $H$. piatan). Furthermore, $H$. kalunga differs from $H$. crenuchoides by interorbital width (27.6-31.3 vs. 34.0-35.6\% of HL), and by caudal peduncle length (13.9-17.4 vs. 17.9-21.8\% of SL); from $H$. hanseni, H. maxillaris, and H. nambiquara by the number of branched anal-fin rays (12-15 vs. 16-19); from $H$. hanseni, $H$. melanura and $H$. nana by the presence of 1-2 maxillary teeth ( $v s$. teeth absent); and from $H$. piatan by the number of principal caudal-fin rays (19vs. 18), number of longitudinal scale serie (33-36 vs. 27-32), and by presence of caudal spot (vs. absence in H. piatan). Hasemania kalunga also differs from $H$. nambiquara by the absence of a broad horizontal black band in the midlateral body.
Description. Morphometric data summarized in Table 1. Body compressed and moderately deep; greatest body depth located between tip of supraoccipital spine and dorsal-fin origin. Dorsal profile of head between vertical through posterior nostril and tip of supraoccipital spine straight or slightly convex. Body profile convex from tip of supraoccipital spine to base of last dorsal-fin ray, and straight from that point to dorsal caudal peduncle margin. Ventral profile of body convex from margin of lower lip to anal-fin origin. Profile of body along anal-fin base posterodorsally slanted. Caudal peduncle deep, profile nearly straight to slightly concave along dorsal and ventral margins. Infraorbital series with five bones. Rhinosphenoid present.

Snout rounded from margin of upper lip to vertical through anterior nostrils. Mouth terminal. Maxilla extending posteriorly to vertical through middle of orbit, slightly curved, and oriented at angle of approximately 45 degrees relative to longitudinal body axis.

Two tooth rows in premaxilla: outer row with 3-4 (4*) trito pentacuspid teeth, central cusp longer; inner row with 5 teeth, gradually decreasing in length from the first to fourth, last distinctly smaller, with 5-7 cusps; central cusp longer and broader than lateral cusps. Maxilla with 1 to $3(2 *)$ teeth, each with 3 to 5 cusps with central cusp largest. Four anteriormost dentary teeth largest, with 5-7 cusps, and followed first by somewhat smaller tooth with 3-5 cusps, and then 5-6 distinctly smaller teeth with 1-3 cusps; central cusp in all teeth two or three times longer and broader than remaining cusps. Cusp tips slightly curved posteriorly and lingually (Fig. 2).

Scales cycloid, with circuli on exposed area of scales and about 10-15 radii. Lateral line incomplete, pored scales 11-17 $\left(11^{*}\right.$, one specimen with 21 , mean $\left.=13 \cdot 3, \mathrm{n}=28\right)$. Longitudinal scale series including lateral-line with 33-36 (33*, mean $=35.2$, $\mathrm{n}=28)$ scales. Scale rows between dorsal-fin origin and lateral line 5-6 $\left(6^{*}\right.$, mean $\left.=5.9, \mathrm{n}=28\right)$; scale rows between lateral line and pelvic-fin insertion $4-5\left(4^{*}\right.$, mean $\left.=4.9, \mathrm{n}=28\right)$. Predorsal scales $11-13$, and arranged in regular series $\left(11^{*}\right.$, mean $=12, \mathrm{n}$ $=27)$. Scales rows around caudal peduncle $14(\mathrm{n}=28)$. Axillary scale on pelvic-fin origin and scale sheath along anal-fin base absent. Caudal-fin scales present only on it base.

Dorsal-fin rays ii,8 (ii, $8^{*}$, one with ii,7, $\mathrm{n}=28$ ); first unbranched ray approximately one-half length of second unbranched ray. Dorsal-fin origin posterior to middle of SL and slightly posterior to vertical through pelvic-fin insertion. Adipose fin absent in all examined specimens. Anal-fin rays ii-iv,13-14 (iii,14*, rarely with 12 or 15 , mean $=13.6, \mathrm{n}=28$ ). First unbranched ray only apparent in the cleared and stained specimens. Longest branched anal-fin ray reaching or surpassing origin of last anal-fin ray when fin depressed. Anal-fin origin situated posterior to vertical through base of last dorsal-fin ray. Anal-fin rays of males bearing one pair of small bony hooks along posterolateral border of each segment of lepidotrichia, usually along last unbranched ray to eighth anterior branched rays. Hooks more numerous along second through fifth branched rays, and usually located along posteriormost branch and distal $1 / 2$ to $2 /{ }_{3}$ of each ray. 


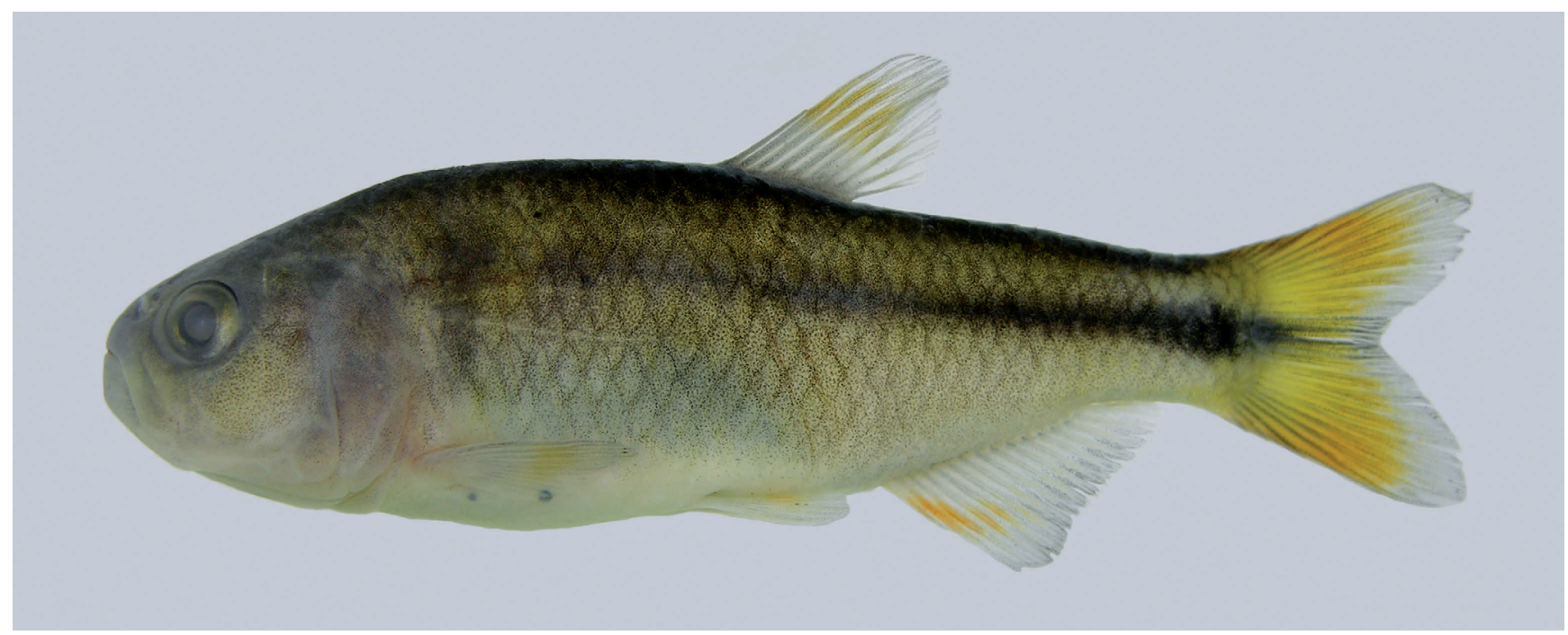

Fig. 1. Hasemania kalunga, MCP 44289, holotype, female, $53.3 \mathrm{~mm}$ SL; Brazil, Goiás State, Cavalcante, tributary of rio das Almas, rio Paranã drainage, upper rio Tocantins basin. Black spots below pectoral fin are nematodes' cysts.

Pectoral-fin rays i, 10-13 $\left(11^{*}\right.$, mean $\left.=11.2, \mathrm{n}=28\right)$. Tip of pectoral fin not reaching pelvic-fin insertion in males and females. Pelvic-fin rays i,6 $(n=28)$. Tip of pelvic fin reaching anal-fin origin in males, falling short of that point in females. Pelvic-fin insertion located slightly anterior to vertical through dorsal-fin origin. Pelvic fin of males usually bearing one small bony hook per lepidotrichia segment along ventromedial border of first to fifth branched rays.

Caudal-fin forked and naked, lobes approximately similar in size, slightly pointed, with 19 principal rays $(\mathrm{n}=28)$. Dorsal procurrent caudal-fin rays $10-12$, and ventral procurrent

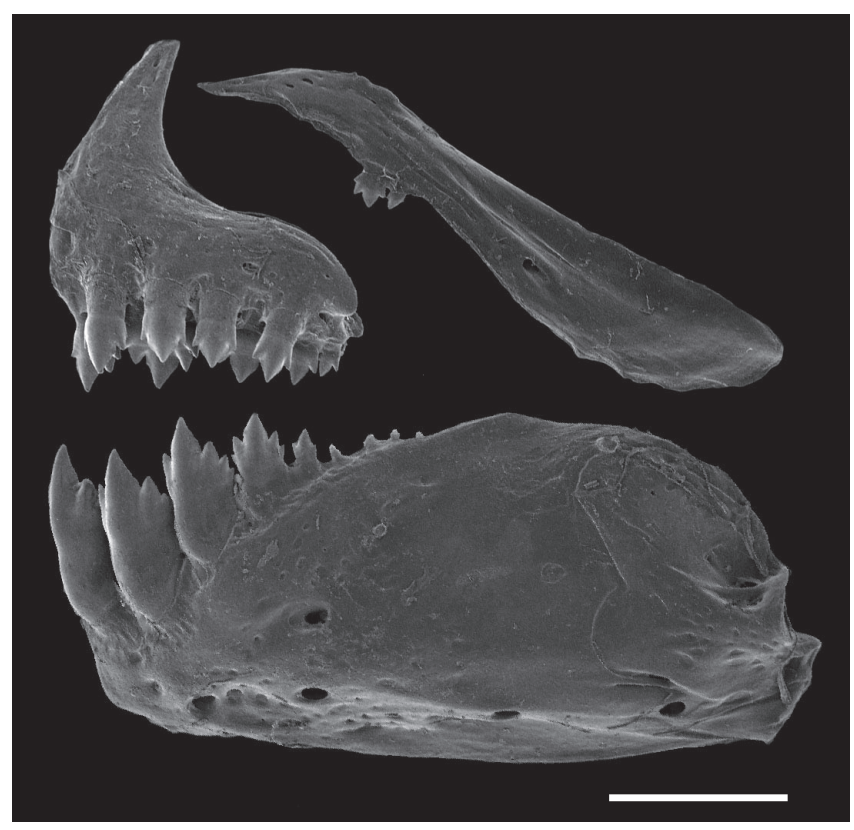

Fig. 2. Upper and lower jaws of Hasemania kalunga, UFRGS 11289, paratype, female, $36.2 \mathrm{~mm} \mathrm{SL}$, lateral view, left side. Scale bar $=1 \mathrm{~mm}$.
Table 1. Morphometric data of holotype (H, female) and paratypes of Hasemania kalunga from the upper rio Tocantins basin, Cavalcante, Goiás State, Brazil. $\mathrm{m}=$ males $(\mathrm{n}=8), \mathrm{f}=$ females $(\mathrm{n}=17) . \mathrm{N}=25$ including the holotype.

\begin{tabular}{lcccc}
\hline & $\mathrm{H}$ & Range & Mean & $\mathrm{SD}$ \\
\hline Standard Length (mm) & 53.2 & $32.2-53.3$ & 38.5 & - \\
& Percents of standard length & & \\
Predorsal distance & 56.4 & $54.0-59.2$ & 57.0 & 1.2 \\
Prepelvic distance & 53.6 & $50.5-55.9$ & 53.2 & 1.4 \\
Prepectoral distance & 29.8 & $27.2-31.0$ & 29.0 & 0.9 \\
Preanal distance & 69.8 & $67.4-71.5$ & 69.4 & 1.2 \\
Depth at dorsal-fin origin(m) & - & $30.7-33.5$ & 31.9 & 0.9 \\
Depth at dorsal-fin origin(f) & 31.5 & $31.4-35.2$ & 33.3 & 1.3 \\
Caudal peduncle depth & 12.7 & $11.6-13.8$ & 12.8 & 0.5 \\
Caudal peduncle length & 13.9 & $13.9-17.4$ & 16.1 & 0.9 \\
Anal-fin base & 19.6 & $17.7-21.9$ & 19.5 & 0.1 \\
Dorsal-fin length & 22.8 & $20.4-26.2$ & 23.2 & 1.4 \\
Pelvic-fin length (m) & - & $14.5-16.5$ & 15.4 & 0.7 \\
Pelvic-fin length (f) & 14.3 & $13.1-15.8$ & 14.5 & 0.7 \\
Pectoral-fin length (m) & - & $19.8-21.5$ & 20.8 & 0.6 \\
Pectoral-fin length (f) & 19.5 & $16.7-20.5$ & 19.2 & 1.1 \\
Head length & 28.1 & $27.2-30.3$ & 28.9 & 0.9 \\
& Percents of head length & & \\
Snout length & 22.3 & $21.2-24.8$ & 23.0 & 0.1 \\
Upper jaw length & 45.5 & $40.6-47.3$ & 44.7 & 1.7 \\
Orbital diameter & 24.0 & $24.0-31.0$ & 28.1 & 1.1 \\
Interorbital width & 30.9 & $27.6-31.3$ & 29.5 & 1.1 \\
\hline
\end{tabular}

caudal-fin rays $9-10(n=5)$.

Precaudal vertebrae 17; caudal vertebrae 17-19; total vertebrae 34-36. Supraneurals 5-6 $(n=5)$. Gill-rakers on upper limb of outer gill arch 6-7, and on lower limb 10-11 $(n=5)$.

Color in alcohol. General body color yellowish to yellowishbrown. Dorsal and dorsolateral portions of head and body pigmented dark brown. Dorsolateral portion of body with scales bordered by dark pigment and forming reticulate pattern. One black humeral spot vertically elongate, wide in dorsal portion and narrowing ventrally; wide dorsal portion of humeral spot located over two or three scales of two to 
three scale series just above lateral line; narrow portion crossing lateral line at third and fourth scales and extending one or two scale series just below lateral line. Body with black pigmented midlateral stripe extending from humeral region to base of middle caudal-fin; dark pigmentation present of middle caudal-fin rays. Midlateral body stripe expanded dorsally and ventrally proximate to caudal-fin base and forming small caudal spot. Fins with scattered dark chromatophores.

Color just after fixation. Color pattern similar to described for alcohol preserved specimens. Specimens examined soon after fixation in formalin with all fins orange to yellowish pigmented.

Sexual dimorphism. Males of Hasemania kalunga are easily differentiated by the presence of small bony hooks on the anal-, and pelvic-fin rays (see Description). Also, males and females differ in pectoral and pelvic-fin lengths, body depth (Table 1), and anal-fin shape, which is nearly straight in males and concave in females. Females also attain larger body sizes than males. From 119 specimens fixed in formalin $10 \%$ only eight are males (31.0-39.0 mm SL), 26 are females (34.1-53.3 $\mathrm{mm} \mathrm{SL})$, and remaining are unsexed specimens (15.5-34.0 mm SL). Gill glands (Burns \& Weitzman, 1996) were not found on first gill arch in males and females.

Ecological notes. All specimens of Hasemania kalunga were collected along the margins of semilentic stretches of a shallow, clear water river, greatest depth of $1.20 \mathrm{~m}$, width of 1.5 to $10 \mathrm{~m}$, with sand and leaves on the bottom, with moderate submerged vegetation (mainly Poaceae and Cyperaceae) and a little riparian vegetation (shrubs). Stomach contents of five specimens showed a large volume of Formicidae, followed by Diptera, Clorophyta, unidentified vegetal organic matter, and insects fragments in lesser amount. No other fish species was collected with H. kalunga in the type locality (Fig. 3). The type locality is situated about $8 \mathrm{~km}$ upstream from Kalunga community where are located some waterfalls, e.g. Cachoeira da Santa Bárbara and Cachoeira da Capivara.

Distribution. Hasemania kalunga is known from its type locality in the upper rio Tocantins basin, tributary of rio das Almas, Cavalcante, Goiás State, Brazil (Fig. 4).

Etymology. The species name, kalunga, is in reference to Comunidade Quilombo Kalunga, descendents of African slaves that lives in the region of the upper rio Tocantins basin (Cavalcante, Teresina de Goiás, and Monte Alegre de Goiás municipalities), in the Chapada dos Veadeiros, near the type locality. Kalunga, in Bantu language, mean protected sacred place. A noun in apposition.

\section{Discussion}

The anal-fin base completely naked in Hasemania kalunga, without a sheath of scales, is uncommon in

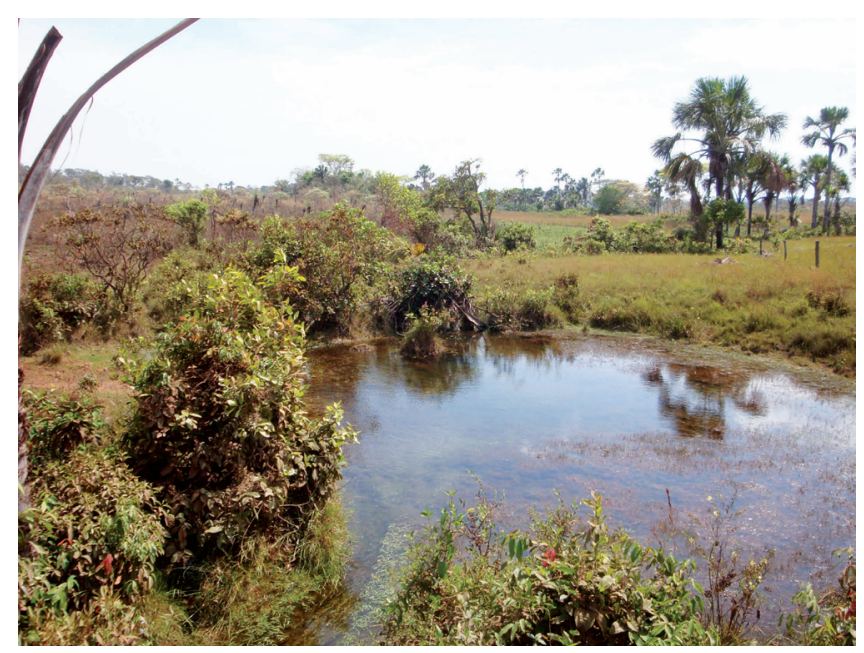

Fig. 3. Type locality of Hasemania kalunga. Brazil, Goiás State, Cavalcante, córrego in the road GO 241 between Cavalcante and Minaçu, tributary of rio das Almas, rio Paranã drainage, upper rio Tocantins basin.

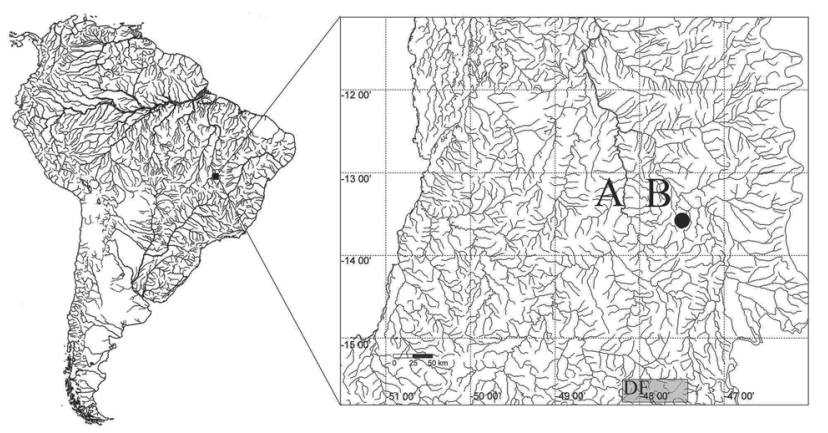

Fig. 4. Distribution of Hasemania kalunga (dot) on upper rio Tocantins, Cavalcante, Goiás State, Brazil. A, rio Maranhão or Tocantins; B, rio Paranã; DF, Distrito Federal. Base map (SA) prepared by Marylin Weitzman.

Characidae, but can be found in Astyanax epiagos (see Zanata \& Camelier, 2008), Hasemania piatan (see Zanata \& Serra, 2010), Iguanodectes spp., in species of the Glandulocaudinae (sensu Menezes \& Weitzman, 2009; e.g. Lophiobrycon weitzmani, Mimagoniates inequalis, M. lateralis, $M$. microlepis, M. rheocharis), Myxiopis aphos, Rhinobrycon negrensis and Spintherobolus spp. (see Weitzman \& Malabarba, 1999). Hasemania kalunga differs from Iguanodectinae, Glandulocaudinae and Spintherobolus (Cheirodontinae) species by not sharing the synapomorphies diagnosing these subfamilies ( $c f$. Moreira, 2003; Menezes \& Weitzman, 2009; and Weitzman \& Malabarba, 1999, respectively), of Myxiops aphos and R. negrensis by the lateral line incomplete ( $v s$. complete) and adipose fin absent ( $v s$. present).

Relationships of Hasemania kalunga with other Hasemania species remain to be investigated, but it is close to $H$. crenuchoides, and $H$. piatan. The monophyly of Hasemania based solely on the lack of an adipose fin has 
been questioned by several authors (Böhlke, 1958; Géry, 1972, 1977; Weitzman \& Malabarba, 1999), and more recently by Lima \& Gerhard (2001), who included a newly described characid species lacking an adipose fin in Hyphessobrycon instead of Hasemania due to an overall body resemblance of the new species, Hyphessobrycon negodagua, with several species of this genus. A similar procedure was adopted previously by Ellis (1911), in the description of Hyphessobrycon taurocephalus that lacks an adipose fin. Hasemania kalunga differs from $H$. negodagua and $H$. taurocephalus in its color pattern, in the number of perforated lateral line scales (11-21 vs. 5-11 and 8-10, respectively), and additionally from $H$. taurocephalus in the number of maxillary teeth (1-3vs. absent).

Hasemania crenuchoides was described by Zarske \& Géry (1999) from córrego Planaltina in the Distrito Federal, rio Paranaíba drainage (upper rio Paraná basin). Recently, Langeani et al. (2007) extended the distribution area of $H$. crenuchoides to rio Grande basin (upper rio Paraná basin), Minas Gerais State. Newly, additional specimens were collected near the type locality and according to F. Langeani (pers. comm.) the specimens from rio Grande basin belongs to a new species. Hasemania kalunga differs from $H$. crenuchoides (non Zarske \& Géry) by number of teeth in the inner series of the premaxilla (five $v s$. four), absence of scale sheath along anal-fin base ( $v s$. presence), head length (27.2$30.3 v s .30 .7-33.7 \%$ of SL), and body depth (30.7-35.2 vs. 34.8$37.3 \%$ of SL).

Hasemania kalunga is similar to Hyphessobrycon hamatus (upper rio Tocantins basin), but differs in the number of branched anal-fin rays (12-15 vs. 16-18), absence of scale sheath along anal-fin base and of an adipose-fin ( $v s$. presence), and absence of bony hooks in the dorsal and pectoral fin of males (vs. presence) (Bertaco \& Malabarba, 2005). Hasemania kalunga is the first species of the genus described from the rio Tocantins basin, possibly due to the limited collecting effort, mainly in the upper portion of this basin. It is one of the largest species of Hasemania along with H. crenuchoides.

The ichthyofauna from the upper rio Tocantins basin, that comprises the drainages above the junction of Paranã and Maranhão or Tocantins rivers (approximately at $12^{\circ} 29^{\prime} \mathrm{S}$ $48^{\circ} 12^{\prime} \mathrm{W}$ ) (Ribeiro et al., 1995), is greatly endemic. This drainage basin possesses various natural waterfalls along of its rivers or streams that can reach up to 120 meters high. Diverse fish species are endemic from the upper portion of the basin, mainly from its headwaters. Apart from new species, other reports on the species composition of that basin are rare (Miranda \& Mazzoni, 2003). The taxa described and restrict from the upper portions of this basin are: Apareiodon argenteus, A. cavalcante (Parodontidae), Leporinus taeniofasciatus (Anostomidae), Characidium stigmosum (Crenuchidae), Acestrocephalus maculosus, Astyanax unitaeniatus, 'Astyanacinus' goyanensis, Creagrutus atrisignum, C. britskii, C. тисіри, C. saxatilis, Hyphessobrycon hamatus, Moenkhausia tergimaculata,
Cheirodontinae new genus and species C (sensu Malabarba, 1998) (Characidae), Cetopsis caiapo, C. sarcodes (Cetopsidae), Aspidoras albater, A. eurycephalus (Callichthyidae), Ancistrus aguaboensis, A. jataiensis, A. minutus, A. reisi, Corumbataia veadeiros, Hemiancistrus micrommatos, Hypostomus ericae, Gymnotocinclus anosteos, Lamontichthys avacanoeiro (Loricariidae), Ituglanis bambui, I. mambai (Trichomycteridae), Pimelodella spelaea (Heptapteridae), Sternarchorhynchus mesensis (Apteronotidae), Cynolebias griseus, C. notatus, Rivulus planaltinus, Simpsonichthys marginatus (Rivulidae). Therewith, Gymnotocinclus and Cheirodontinae new genus (L. Malabarba, pers. comm.) are endemic genera from upper rio Tocantins basin. We reinforced that the upper rio Tocantins represents a high area of fish endemism in the ecoregion Tocantins-Araguaia (sensu Abel et al., 2008) and, thereby, should receive a special attention of governmental environmental agencies to the implementation of public policies for conservation of this area as relevant patrimony of biological diversity.

Comparative material (all from Brazil). In addition to the comparative material listed in Bertaco \& Malabarba (2007), the following specimens were analyzed: 'Astyanacinus' goyanensis, UFRGS 11291, 80, 5 c\&s, 18.5-79.9 mm SL, Goiás State, Alto Paraíso de Goiás, rio dos Couros, upper rio Tocantins basin. Hasemania crenuchoides, MZUSP 52732, holotype, $64.1 \mathrm{~mm}$ SL, Distrito Federal, Planaltina, córrego Planaltina, rio São Bartolomeu basin; DZSJRP 11039, 5 of 47, 37.3-58.9 mm SL, Distrito Federal, Brasília, córrego Paranoazinho, rio São Bartolomeu basin. Lophiobrycon weitzmani, MNRJ 31664, 1 of 226, 40.0 mm SL, Minas Gerais, São João Batista/Capitólio, ribeirão das Capivaras. Mimagoniates inequalis, UFRGS 8759, 26, 16.8-36.1 mm SL, Rio Grande do Sul, Amaral Ferrador, unnamed stream on Fazenda Ferraria. Mimagoniates lateralis, UFRGS 9007 , 80, 17.5-29.8 mm SL, Santa Catarina, São Francisco do Sul, arroio Ribeiro on Tapera neighborhood. Mimagoniates microlepis, UFRGS 10348, 59, 22.0-45.1 mm SL, São Paulo, Iguape, stream on margin of highway between Iguape and Icapara municipality. Mimagoniates rheocharis, UFRGS 8831, 9, 27.3-32.0 mm SL, Rio Grande do Sul, Maquiné, rio Amola Faca. Myxiops aphos, MCP 35007, 4 paratypes, 41.6$48.8 \mathrm{~mm} \mathrm{SL}$, Bahia, Lençóis, rio Lençóis, tributary of rio Paraguaçu, $3 \mathrm{~km}$ upstream of Lençóis city, above Cachoeira do Serrano. Spintherobolus ankoseion, UFRGS 9013, 19.1$27.8 \mathrm{~mm}$ SL, Santa Catarina, São Francisco do Sul, arroio Ribeiro on Tapera neighborhood. Spintherobolus broccae, UFRGS 10179,1, 19.3 mm SL, São Paulo, Bertioga, km 208 highway Rio-Santos. Spintherobolus leptoura, UFRGS 10340, 4, 20.8-22.0 mm SL, São Paulo, Iguape, stream on margin of highway between Iguape and Icapara municipality. Rhinobrycon negrensis, UFRGS 10393, 200, 16.6-30.3 mm SL, Amazonas, Manaus, left margin of rio Negro, near community Santa Maria. 


\section{Acknowledgements}

We thank to Guilherme Frainer (UFRGS) by help in the specimens collecting, Andréia Turcati (UFRGS) by helping with the analysis of stomach contents, Francisco Langeani (UNESP) by permit the analysis of $H$. crenuchoides, Luiz R. Malabarba (UFRGS) with the photo of holotype, information about Cheirodontinae new genus and species $\mathrm{C}$, and by suggestions in the manuscript. Lilian Casatti (UNESP) by assistance on map. We thank to Centro de Microscopia Eletrônica (UFRGS) for the SEM preparations. VAB is financed by a postdoctoral fellowship from CNPq (Proc. 150042/20094). FRC is a doctoral fellowship from CNPq (Proc. 141028/ 2007-6). Fieldwork support was in part provided by CNPq (proc. 479412/2008-1). Collecting permits were provided by Instituto Brasileiro do Meio Ambiente e dos Recursos Naturais Renováveis - IBAMA (\# 1507-1).

\section{Literature Cited}

Abell, R., M. L. Thieme, C. Revenga, M. Bryer, M. Kottelat, N. Bogutskaya, B. Coad, N. Mandrak, S. Contreras-Balderas, W. Bussing, M. L. J. Stiassny, P. Skelton, G. R. Allen, P. Unmack, A. Naseka, R. Ng, N. Sindorf, J. Robertson, E. Armijo, J. V. Higgins, T. J. Heibel, E. Wikramanayake, D. Olson, H. L. López, R. E. Reis, J. G. Lundberg, M. H. Sabaj-Pérez \& P. Petry. 2008. Freshwater Ecoregions of the World: A new map of biogeographic units for freshwater biodiversity conservation. BioScience, 58(5): 403-414.

Bertaco, V. A. \& C. A. S. Lucena. 2006. Two new species of Astyanax (Ostariophysi: Characiformes: Characidae) from eastern Brazil with a synopsis of the Astyanax scabripinnis species complex. Neotropical Ichthyology, 4(1): 53-60.

Bertaco, V. A. \& L. R. Malabarba. 2005. A new species of Hyphessobrycon (Teleostei: Characidae) from the upper rio Tocantins drainage, with bony hooks on fins. Neotropical Ichthyology, 3(1): 83-88.

Bertaco, V. A. \& L. R. Malabarba. 2007. A new species of Hasemania from the upper rio Tapajós drainage, Brazil (Teleostei: Characiformes: Characidae). Copeia, 2007(2): 350-354.

Böhlke, J. E. 1958. Studies on fishes of the family Characidae. $N^{\circ}$ 14. A report on several extensive recent collections from Ecuador. Proceedings of the Academy of Natural Sciences of Philadelphia, 110: 1-121.

Burns, J. R. \& S. H. Weitzman. 1996. Novel gill-derived gland in the male swordtail characin, Corynopoma riisei (Teleostei: Characidae: Glandulocaudinae). Copeia, 1996(3): 627-633.

Eigenmann, C. H. 1921. The American Characidae. Part 3. Memoirs of the Museum of Comparative Zoology, 43: 208-310.

Ellis, M. D. 1911. On the species of Hasemania, Hyphessobrycon, and Hemigrammus collected by J. D. Haseman for the Carnegie Museum. Annals of the Carnegie Museum, 8: 148-163.

Fink, W. L. \& S. H. Weitzman. 1974. The so-called cheirodontin fishes of Central America with descriptions of two new species (Pisces: Characidae). Smithsonian Contributions to Zoology, 172: 1-46.

Géry, J. 1972. Corrected and supplemented descriptions of certain characoid fishes described by Henry W. Fowler, with revisions of several of their genera. Studies on Neotropical Fauna and Environment, 7: 1-35.

Géry, J. 1977. Characoids of the World. Neptune City, NJ, T.F.H. Publications, 672p.
Langeani, F., J. P. Serra, F. R. Carvalho, H. F. Chaves, C. P. Ferreira \& F. O. Martins. 2007. Fish, Hasemania crenuchoides Zarske and Géry, 1999 (Ostariophysi: Characiformes: Characidae): Rediscovery and distribution extension in the upper rio Paraná system, Minas Gerais, Brazil. Check List, 3(1): 119-122.

Lima, F. C. T. \& P. Gerhard. 2001. A new Hyphessobrycon (Characiformes: Characidae) from Chapada Diamantina, Bahia, Brazil, with notes on its natural history. Ichthyological Exploration of Freshwaters, 12(2): 105-114.

Lima, F. C. T., L. R. Malabarba, P. A. Buckup, J. F. Pezzi da Silva, R. P. Vari, A. Harold, R. Benine, O. T. Oyakawa, C. S. Pavanelli, N. A. Menezes, C. A. S. Lucena, M. C. S. L. Malabarba, Z. M. S. Lucena, R. E. Reis, F. Langeani, L. Casatti, V. A. Bertaco, C. Moreira \& P. H. F. Lucinda. 2003. Genera Incertae Sedis in Characidae. Pp. 106-169. In: Reis, R. E., S. O. Kullander \& C. J. Ferraris Jr. (Eds.). Check List of the Freshwater Fishes of South and Central America. Porto Alegre, Edipucrs, 729p.

Malabarba, L. R. 1998. Monophyly of the Cheirodontinae, characters and major clades (Ostariophysi: Characidae). Pp. 193-233. In: Malabarba, L. R., R. E. Reis, R. P. Vari, Z. M. S. Lucena \& C. A. S. Lucena (Eds.). Phylogeny and classification of neotropical fishes. Porto Alegre, Edipucrs, 603p.

Menezes, N. A. \& S. H. Weitzman. 2009. Systematics of the neotropical fish subfamily Glandulocaudinae (Teleostei: Characiformes: Characidae). Neotropical Ichthyology, 7(3): 295-370.

Miranda, J. C. \& R. Mazzoni. 2003. Composição da ictiofauna de três riachos do Alto Rio Tocantins - GO. Biota Neotropica, 3(1): 1-11.

Moreira, C. 2003. Subfamily Iguanodectinae. Pp. 172-176. In: Reis, R. E., S. O. Kullander \& C. J. Ferraris Jr. (Eds.). Check List of the Freshwater Fishes of South and Central America. Porto Alegre, Edipucrs, 729p.

Ribeiro, M. C. L. B., M. Petrere-Jr. \& A. A. Juras. 1995. Ecological integrity and fisheries ecology of the Araguaia-Tocantins river basin, Brazil. Regulated Rivers Research and Management, 11: 325-350.

Taylor, W. R. \& G. C. van Dyke. 1985. Revised procedures for staining and clearing small fishes and other vertebrates for bone and cartilage study. Cybium, 9: 107-119.

Weitzman, S. H. \& L. R. Malabarba. 1998. Perspectives about the phylogeny and classification of the Characidae (Teleostei: Characiformes), Pp. 161-170. In: Malabarba, L. R., R. E. Reis, R. P. Vari, Z. M. S. Lucena \& C. A. S. Lucena (Eds.). Phylogeny and classification of neotropical fishes. Porto Alegre, Edipucrs, 603p.

Weitzman, S. H. \& L. R. Malabarba. 1999. Systematics of Spintherobolus (Teleostei: Characidae: Cheirodontinae) from eastern Brazil. Ichthyological Exploration of Freshwaters, 10(1): $1-43$.

Zanata, A. M. \& P. Camelier. 2008. Two new species of Astyanax (Characiformes: Characidae) from upper rio Paraguaçu and rio Itapicuru basins, Chapada Diamantina, Bahia, Brazil. Zootaxa, 1908: 28-40.

Zanata, A. M. \& J. P. Serra. 2010. Hasemania piatan, a new characid species ( Characiformes: Characidae) from headwaters of rio de Contas, Bahia, Brazil. Neotropical Ichthylogy, 8(1): 21-26.

Zarske, A. \& J. Géry. 1999. Hasemania crenuchoides, spec. nov. ein neuer Salmler aus dem Bundesstaat Goias, Brazilien. Spixiana, 22(1): 91-96.

Accepted January 21, 2010

Published March 31, 2010 